INTERMARUM: history, policy, culture. - Issue 6.

UDC $94(477+438)(083.132)$

DOI $10.35433 /$ history. 11195

Potapenko Maksym,

$\mathrm{PhD}$ in History, Associate Professor at the Department of History of Ukraine, Nizhyn Mykola Gogol State Univercity dulen@ukr.net

ORCID: https://orcid.org/0000-0002-0000-8892

\title{
KAZIMIERZ DOMOSLAWSKI'S TESTIMONIES ON THE ACTIVITIES OF THE POLISH MILITARY ORGANIZATION IN KYIV IN 1915-1918
}

\section{Abstract}

The full text of the testimonies of the outstanding Polish politician Kazimierz Domostawski on the initial activities of the Polish Military Organization in Ukraine is introduced into the scientific discourse. The Kyiv branch of this organization played an important role in the national life of the Poles of Dnieper Ukraine during the First World War. These testimonies were recorded by Henryk Jabłonski in late 1933 during the collection of oral evidence for the study of Polish autonomy in the Dnieper Ukraine in 1917 1918. Kazimierz Domostawski was an employee of the Polish Society for Assistance to Victims of War, led the activities of the Kiev branches of the student 'Korporacja' and the Polish socialist party (revolutionary fraction). His political career peaked in 1917. Then he became a member of the Central Rada of Ukraine, a member of the Kiev city Duma, the head of the II Conference of the Polish socialist party in Russia, as well as an employee of two bodies of Polish national self-government in Ukraine, namely the Polish Executive Committee in Rus and (Vice)Secretariat of Polish Affairs of the General Secretariat of the Central Rada. The fact that Kazimierz Domostawski was participant of the Polish Military Organization is little known among historians. It means that, there were the close contacts between the legal Polish socialist party (revolutionary fraction) and the underground Polish Military Organization. The main topic of the testimonies is the activities of the Kiev branch of the Polish Military Organization in 1915 - 1918. That time was one of the most decisive periods of the organization. In the study the internal and external criticism of the source is carried out, its high informative value is confirmed. The correlation of these testimonies with the later memoirs of 
IНТЕРМАРУМ: історія, політика, культура. - Вип. 6.

Kazimierz Domostawski, published in 1923, is analyzed. The proof of the high level of reliability of the testimony is that all the mentioned persons were members of the Polish Military Organization (the results of the researches of Alexander Golichenko).

Keywords: Kazimierz Domosławski, Henryk Jabłoński, Polish Military Organization, Kyiv, Ukrainian revolution $1917-1921$.

Introduction. The participation of Poles in the political life of Ukraine during the World War I and the revolution influenced the development of Ukrainian-Polish relations throughout the 20th century. For example, it played a leading role in the politics of the PolishUkrainian understanding of the Volyn governor Henryk Józewski. Similarly, the "Ukrainian experience" of people around Jerzy Giedroyc influenced the formation of his geopolitical project of an independent Ukraine as a barrier to Russian imperialism. This idea is still used today in Polish diplomacy.

An important but insufficiently researched aspect of this topic is the activity of the Polish Military Organization (PMO) on the territory of the Dnieper Ukraine ${ }^{1}$. Until November 1918 its Ukrainian branches managed to implement several successful sabotage and reconnaissance operations, as well as to conduct a productive campaign to mobilize young people into the Polish army (Holiczenko, 2010, p. 210) (Nałęcz, 1984, p. 155-165).

Due to the conditions of conspiracy oral orders prevailed rather than the written ones. Therefore, the lack of reliable primary sources has become a problem for modern researchers. This problem is only partially offset by the eyewitnesses' testimonies that were recorded in the interwar period. They are still rare and usually contain superficial information. During the anti-Polish repressions in the USSR in the $20-$ 30 s of the 20th century, it was dangerous to name members of the organization or disclose details of activities. Therefore, the introduction of new sources into the scientific discourse remains one of the main tasks for researchers.

19 Ukrainian provinces of the former Russian Empire, namely Kiev, Volyn, Podolsk, Chernihiv, Poltava, Kharkiv, Ekaterinoslav, Kherson and Tauride. 
INTERMARUM: history, policy, culture. - Issue 6.

Purpose. Below we will consider two pieces of Kazimierz Domosławski's $(1893$ - 1960) testimonies. His stay in the Dnieper Ukraine was not long. After the outbreak of the war, he interrupted his studies at the University of Graz and moved to his family in Volyn province, and then to Kiev to his brother. He left for Warsaw in February 1919. During this short but turbulent time, he became a prominent figure in local Polish social and political life. He was an employee of the Polish Society for Assistance to Victims of War, led the activities of the Kiev branches of the student 'Korporacja' and the Polish socialist party (revolutionary faction). His political career peaked in 1917. Then he became a member of the Central Rada of Ukraine, a member of the Kiev city Duma, the head of the II Conference of the Polish socialist party in Russia, as well as an employee of two bodies of Polish national self-government in Ukraine, namely the Polish Executive Committee in Rus and (Vice)Secretariat of Polish Affairs of the General Secretariat of the Central Rada (Wawrzyńska, 1985, p. 615-616).

Note that these testimonies still remain barely known. Henryk Jabłoński (Jabłoński, 1939a) (Jabłoński, 1939b) (Jabłoński, 1948), Kazimierz Wierzejski (Wierzejski, 1939) and Alexander Holichenko (Holiczenko, 2012) occasionally used them in their studies. Moreover, the latter considered them while elaborating several biograms of PMO members in Ukraine, including Kazimierz Domosławski himself (Holiczenko, 2012, p. 82).

Presentation. The testimonies presented below were recorded by the young historian Henryk Jabłoński (1909 - 2003), who researched the Polish national self-government as a part of the executive bodies of the Ukrainian People's Republic. This refers to the activities of the (Vice)Secretariat of Polish Affairs of the General Secretariat, which was reorganized into the Ministry of Polish Affairs shortly after the proclamation of the IV Universal.

In 1933 he managed to meet at least 15 leaders of Polish social and political life in the early 20th century Dnieper Ukraine ${ }^{2}$. A significant

${ }^{2}$ Beside Kazimierz Domosławski there were also Stanisław Dembecki, Ludgar Groholski, Stanisław Kalinowski, Antonina Krzyzanowska, Roman Knoll, 
IНТЕРМАРУМ: історія, політика, культура. - Вип. 6.

part of them belonged to the leadership of the Polish independence movement and promoted Józef Pilsudski's ideology. The testimonies were usually recorded during personal conversations between the respondent and Henryk Jabłoński, who directed the conversation by means of questions. Sometimes follow-up meetings were held to clarify and deepen individual plots. For example, he met Stanisław Kalinowski three times (June 19, August 28 and September 10, 1933) (CAW. Sygn. 400.2831). During the conversations Henryk Jabłoński kept notes, which were subsequently typewritten. The final stage of recording the testimonies was re-reading and proofreading of the typewritten texts.

Henryk Jabłoński used these testimonies as an aide-Memoire. The scheme and the facts were essential in them, not the form of the record. Therefore, the testimonies are saturated with short chopped sentences, ununified abbreviations, occasional tautologies, rare examples of the respondent's direct speech, but rather frequent comments of the interviewer. Now most of these testimonies are stored in the manuscript collection of the Central military archive in Warsaw.

Henryk Jabłoński attached great importance to these records. They compensated for the lack of primary documents that had vanished or were stored in private archives inaccessible to him. That is why he used them as a factual and plot backbone of his research. Its first results were published in 1939. The magazine "Niepodległość" included two parts of an extensive article "Ministerium Spraw Polskich Ukraińskiej Republiki Ludowej 1917 - 1918". Due to the German-Soviet occupation of the II Polish republic, it was not finished. The material shed light on the activities up to July 1917 and stopped on the twists and turns of the formation of the Polish representation in the Central Rada. Consequently, the presentation of the main material was not even begun (Jabłoński, 1939a) (Jabłoński, 1939b). Henryk Jabłoński continued his research after the war, when he started working at the University of Warsaw. In 1948 he published a thesis named "Polska autonomia narodowa na Ukrainie 1917 - 1918" (Jabłoński, 1948). Henryk

Witold Matuszewski, Roman Niwiński, Wlodzimierz Redlich, Kazimierz Rożniewicz, Walerian Rudnicki, Antonina Sokolich, Alexander SplawaNejman, Stanisław Stempowski and Leon Trzeciak. 
INTERMARUM: history, policy, culture. - Issue 6.

Jabłoński estimated the scientific value of his publication rather modestly. He noted that he sought to complement the historiographical discourse with the pecularities of the Polish political life in the Dnieper Ukraine during the revolution, "...to cause discussion, maybe even protests, or at least outrage" (Jabłoński, 1948, p. 16). Today, this publication remains the most thorough research on the topic.

Henryk Jabłoński met Kazimierz Domosławski at least three times. The first meeting took place on September 27, 1933. The second was on November 29 of the same year. The date of the third meeting is unknown, but most likely it was held not much later than the second one. As a result, there appeared three testimonies: the first did not have a title (11 pages), the second was named "P.O.W." (5 pages) and the third one was entitled "Organizacje i ludzie" (2 pages) (CAW. Sygn. 400.2829). However, the latter testimony was an addition to the first two. It lists the people who could confirm and expand Kazimierz Domosławski's story. It is important that the Kazimierz Domosławski's testimonies were among the last (if not solely the last) of those that were collected by Henryk Jabłoński.

Actually, only the last two testimonies are of interest in the study of the history of the PMO in Ukraine. The first testimony, which was untitled and published in 1923, is largely a variation of the memoirs of Kazimierz Domosławski on the time of the Central Rada and Pavlo Skoropadsky's Hetmanate (Domosławski, 1923). It contains only one short story, which directly concerns the PMO. This is a story about the role of Józef Bromirski in the relations between the student independence organizations in Kyiv during the World War I, namely the 'Korporacja', 'Filarecja' and the 'Unia Młodzieży PostępowoNiepodległościowej'. He opposed their Association, because he suspected the existence of provocateurs among the members of the 'Filarecja' (CAW. Sygn. 400.2830. P.2).

An important feature is that the material is presented in the first person, rather than in the third as in most other testimonies. Along with this, there are no traces that Henryk Jabłoński directed the conversation with questions. All those facts suggest that the testimony was written with Kazimierz Domosławski's own hand. It is possible that Henryk Jabłoński's involvment was limited only to the preparation of the typescript. 
IНТЕРМАРУМ: історія, політика, культура. - Вип. 6.

In General, Kazimierz Domosławski's testimonies are a highly informative source. Firstly, they are written by one of the leaders of the PMO Kiev branch. Kazimierz Domosławski held concurrently the positions of Kyiv city commandant and the instructor. Secondly, he was in close contact with the head of the PMO in Ukraine Józef Bromirski and received important first-hand messages. Thirdly, he names more than 20 names of PMO members (CAW. Sygn. 400.2829). This contrasts significantly with the memories of other undergrounders, which are usually sketchy and depersonalized (Ziemiański, 1930). Thus Kazimierz Domosławski's testimonies can enjoy a high degree of credibility. The absolute majority of the people mentioned by the author appear in the list of PMO in Ukraine members, which was reproduced by Alexander Holichenko (Holiczenko, 2012). The big intrigue is that Kazimierz Domosławski mentions Wanda, the wife of Leon Wasilewski, the Creator of Eastern European politics of the II Polish rupublic, among the women of the Polish underground in Kyiv (CAW. Sygn. 400.2829, P.7). Unfortunately, there are no sources to check this information.

Chronologically, the testimonies begin in the second half of 1915, when, as Kazimierz Domosławski recalls, he came to Kiev. The upper chronological limit in the testimonies is not clearly delineated, but most likely it lies in the middle of 1918. The events of March are mentioned, when, after the resignation of Józef Bromirski, the leadership of the PMO in Ukraine passed to Tadeusz Schätzel and Bogusław Miedzyński, who arrived from Warsaw. But no mention is made of the vicissitudes with the appointment of the General command commandant of PMO 3, which culminated in the confirmation of the candidacy of Leopold LisKula (Harski, 1930, p.226) (Holiczenko, 2012, p.15).

It should be noted that this chronological period in the memoirs is not represented consistently. The main attention is paid to the second half of 1915 to the beginning of 1917. This period is connected with the description of the organization, focus areas, recruitment of new members, and external contacts. Together they provide a picture of a relatively weak underground organization that was not engaged in practical activities, but rather in the creation of the "PMO legend" rumors of a strong "mysterious power" (CAW. Sygn. 400. 2829. P.2). The events of the spring of 1918 are covered sporadically. The reason 
INTERMARUM: history, policy, culture. - Issue 6.

for this was that the position of Kazimierz Domosławski in the PMO Kiev branch significantly weakened after the demission of Józef Bromirsky. At the same time, the events of the revolutionary 1917 are not mentioned at all. In the memoirs published in 1923, he appeared to be one of the leaders of the Polish socialist party (revolutionary faction) and did not mention his involvement into PMO (Domosławski, 1923).

Comparison of testimonies and memoirs of Kazimierz Domosławski indicate that he actually "catapulted" from the underground to the legitimate politics. It was not a single case. Józef Bromirski in 1917 suddenly became quite a recognizable politician too. He joined the Board of the Polish democratic Union in Rus, was a Kiev County delegate of the Polish democratic Central in Ukraine and a member of Kiev city Duma representing the Polish Voters List (Wołoszynowski, 1917), (Zamarajew, 1917). Another example is a member of the PMO Kiev branch Henryk Józewski, who in the autumn of 1917 became the head of one of the departments of the Secretariat of Polish Affairs of the Ukrainian People's Republic (Jabłoński, 1948, p.57). Thus, we can talk about the fact that the PMO Kyiv branch used the tactics of introducing its members to the leadership of legitimate organizations, and especially to political parties. In this way, the PMO established a covert control over such institutions. This also explains the decrease in the activity of PMO in Ukraine during 1917. Its leaders were involved in high politics.

Conclusions. Altogether, the testimonies of Kazimierz Domosławski are a valuable source for studying the activities of the PMO in Ukraine during the World War I and the Ukrainian revolution. They contain a large amount of information, in particular personal data. They may be useful for the study of the influence of the independence underground on the legal political life of Poles in Kyiv. The testimonies also allow us to significantly revise the "Ukrainian period" of Kazimierz Domosławski's biogaphy. His activities in the PMO preceded his membership in the Polish socialist party (revolutionary faction). He was primarily an undergrounder, not a political figure. 
IНТЕРМАРУМ: історія, політика, культура. - Вип. 6.

\section{BIBLIOGRAPHY}

Harski, I. (1930). Komendant naczelny K.N. 3 Jot-Bromirski. Polska Organizacja Wojskowa. Szkice $i$ wspomnienia. Warszawa, pp. 223-227.

Domosławski, K. (1923). Udział P.P.S. w życiu państwowem Ukrainy w latach 1917 - 1918. W trzydziesta rocznice. Księga pomiatkowa P.P.S. Warszawa, pp. 248-255.

Holiczenko, A. (2010). Niektórze aspekty działalności Polskiej organizacji wojskowej na Ukrainie w latach 1914-1920. Echa Przeszłości, №10, pp.195-211.

Holiczenko, A. (2012). Żotnierze tajnego frontu: lista imienna KN3 POW-Wschód, 1914 - 1921. Olsztyn.

Jabłoński H. (1933). Relacja ustna Kazimierza Domosławskiego, Sygn. 400.2829. Warszawa: Centralne Archiwum Wojskowe, pp. 1-7.

Jabłoński H. (1933). Relacja ustna Kazimierza Domosławskiego, Sygn. 400.2830. Warszawa: Centralne Archiwum Wojskowe, pp. 1-11.

Jabłoński H. (1933). Relacja ustna Stanisława Kalinowskiego, Sygn. 400.2831. Warszawa: Centralne Archiwum Wojskowe, pp. 1-9.

Jabłoński, H. (1939a). Ministerium Spraw Polskich Ukraińskiej Republiki Ludowej 1917 - 1918. Niepodległość. Casopismo poświęcone najnowszym dziejóm Polski. Warszawa, T.XX. Z.1(54), pp. 65-88.

Jabłoński, H. (1939b). Ministerium Spraw Polskich Ukraińskiej Republiki Ludowej 1917 - 1918. Niepodległość. Casopismo poświęcone najnowszym dziejóm Polski. Warszawa, T.XX. Z.2(55), pp. 260-268.

Jabłoński, H. (1948). Polska autonomia narodowa na Ukrainie 1917 - 1918. Warszawa.

Nałęcz, T. (1984). Polska Organizacja Wojsowa: 1914 - 1918. Wrocław.

Volos, M. (2009). Polskaya voennaya organizatsiya v Rossii I na Ukraine v 1917 - 1918 godakh. Revolyutsionnaya Rossiya 1917 goda $i$ polskiy vopros: novye istochniki, novye vzglyady. Moskva, pp. 195-216. [in Russian].

Wawrzyńska, W. (1985). Domosławski Kazimierz. Słownik biograficzny działaczy polskiego ruchu robotniczego. Tom.I. A - D. Warszawa, pp. 615-616.

Wierzejski, W. (1939). Fragmenty z dziejów polskiej młodzieży akademickiej w Kijowie 1834 - 1920. Warszawa. 
INTERMARUM: history, policy, culture. - Issue 6.

Wołoszynowski, J. (Ed.). (1917). Kronika. Dziennik Kijowski, № 83, 28 marca (10 kwitnia), p. 3.

Zamarajew, U. (Ed.). (1917). Komunikat. Gazeta Narodowa, № 93, 27 października (9 listopada), p. 1.

Ziemiański, I. (1930). Zarys historji P.O.W. na Wschodzie. Polska Organizacja Wojskowa. Szkice i wspomnienia. Warszawa, pp. 215-222.

\section{RELACJA USTNA \\ P.O.W.}

Do Kijowa przyjechałem w drugiej połowie 1915 r. i kontakt z P.O.W. nawiązałem przez p. J. Moszczeńskiego ${ }^{3}$ który mnie do P.O.W. skierował i zameldowałem się u Józefa Bromirskiego ${ }^{4}$ /pseudonim organizacyjny: „Jot”/. Był on urzędnikiem Banku Handlowego.

Bromirski wyznaczył mnie na komendanta miejscowego i jednocześnie powierzył mi robotę instruktorską.

Jeżeli chodzi o charakterze działalności P.O.W. w tym okresie - to była ona wyłącznie przygotowawcza, żadnej czynnej akcji /w charakterze bojowym/ nie przejawialiśmy. Srodki finansowe były bardzo szczupłe i pochodziły ze składek członków /istniało stałe powszechne opodatkowanie/, - oprócz tego pomagał finansowo Bromirski, prawdopodobnie częściowo $\mathrm{z}$ własnych funduszów, a częściowo od swoich znajomych i przyjacioł.

Ramy organizacyjne były bardzo szczupłe i Bromirski celowo nie dążył do zbytniego rozszarzenia organzacji pragnąc mieć element pewny ideowo, a z drugej strony pragnąc zachować choćby szczupła organizacje w całości bez wsypy, aby przetrwać w ten sposób do chwili decydującej, w której organizacja ta mogłaby się stać bazą dla szerszej roboty. To zadanie zostało wykonane. $\mathrm{Z}$ drugiej strony Bromirskiemu chodziło o to, żeby $\mathrm{w}$ społeczeństwie polskim trwała świadomość istnienia takiej organizacji, ale bez dokładnej informacji o jej istotnej

3 Józef Moszczeński (code names «Ryk», «Edmund Ryk»), born in 1894. At the time of the events was on military service in the Russian army. Probably took a course of study in the 4th school of ensigns in Kiev.

${ }^{4}$ Józef Bromirski (code names «Jot», «Piotrowski»), born in 1865. Founder and the first head of PMO Kyiv branch. 
IНТЕРМАРУМ: історія, політика, культура. - Вип. 6.

sile i żeby tego rodzaju legenda istnienia jakiejś tajemniczej siły podtrzymywała $\mathrm{w}$ spoleczeństwie polskim nastrój niepodłeglościowy. Było to mądre i rozważne, bo i tak wtedy szersza działalność była niemożliwa, a chodziło aby ten jakiś ognik tlił, a z drugiej strony aby w społeczeństwie narastała potencjalna energja.

Dziedziny pracy. Pierwsza rzeczą była praca wyszkoleniowa. Bromirski kładł bowiem duży nacisk na jej systematyczność. Co pewien czas przychodziłem do niego, do Banku i tam, na korytarzu, na ławeczce i w sposób nie zwracający uwagi, skałdałem mu ustne raporty o postępach prac wyszkoleniowych. W rozmowach tych kładł on nacisk z jednej strony na punktualność, systematyczność zbiórek, a z drugiej strony na podtrzymanie napięcia ideowego.

Mieliśmy trzy męskie sekcje, ćwiczące, z których dwie składały się $\mathrm{z}$ młodzieży akademickiej, a trzecia $\mathrm{z}$ młodzieży skół średnich. Przerabialiśmy różne przedmioty teoretyczne, następnie trochę musztry formalnej w pokoju, chwyty bronią /były, zdaje się, jeden czy dwa karabiny/, oprócz tego kilkakrotnie wychodziliśmy na ćwiczenia polowe w okolice Kijowa, chociaż tu było trudniej ze względu na to, że ja nie miałem wykształcenia $\mathrm{w}$ zakresie służby piechoty, a tylko wykształcenie artyleryjskie, a inni członkowie organizacji także nie byli przygotowani.

Obok sekcyj męskich istniała sekcja kobieca.

Oprócz sekcyj czynnych - ćwiczących była pewna ilość czlonków rezerwie.

Jako miejsce zbiórek służyło najczęściej mieszkanie Mackiewicza ${ }^{5}$ przy ul. Wieliej Wasilkowskiej $104 /$ / / Mieszkanie to było dosyć odległe, nie zwracało uwagi, - tam mielismy broń i przerabialiśmy chwyty bronią.

Potem bywały zbiórki u Sułkowskiego ${ }^{6}$, u Milanowskiego ${ }^{7}$ i u Radziejowskiej ${ }^{8}$.

\footnotetext{
${ }^{5}$ Most likely is Karol Mackiewicz (code name «Pawlowski»).

${ }^{6}$ Bohdan Sułkowski (code names «Ostrog», «Kruk»), a member of PMO Kyiv branch since 1915 року. In 1915-1916 together with Henrik Yuzevskim was in exile in Saratov.

${ }^{7}$ Most likely is Władysław Milanowski (code name «Mili»), born in 1898.

${ }^{8}$ Most likely is Natalia Radziejowska, member of a women section of PMO 96
} 
INTERMARUM: history, policy, culture. - Issue 6.

Drugą dziedziną pracy była technika paszportowa. Tą sprawą zajmował się Wincenty Narbutt ${ }^{9}$ i nieżyjący już dziś Mieczysław Arciniowski ${ }^{10}$.

Trzecią dziedziną była pomoc jeńcom. Zazaczyła się ta akcja głownie po bitwie pod Kostjuchnówką ${ }^{11}$. Przechowywaliśmy ich, dawali mieszkanie, odzież, dowody, a nawet wynajdywali zajęcia.

Z bardziej znanych, którzy się tam przewinęli warto wymienić Zulanfa $^{12}$. Był on u nas na jednej zbiórce i pokazywał chwyty, jakie były stosowane w legionach. Było to w mieszkaniu Radziejowsiej.

Jeżeli chodzi o werbunek członków to Bromirski był bardzo ostrożny i nie zalecał specjalnie werbować nowych kandydatów, ale wyrażał się, że „przyjmować tych, którzy nas sami szukać będą”.

Zadnej pisaniny nie było. Rozkazy i raporty wydawane i składane były ustne, żadnych śladów pisanych pracy nie było. Członowie mieli pseudonimy organizacyjne ${ }^{13}$ i zasadniczo mogli znać kogoś z terenu akademickiego, a będąc $\mathrm{w}$ innej sekcji, nie wiedzieli, że należy on do P.O.W.

W tym stanie organizacja przetrwała do przyjazdu Schätzla ${ }^{14}$ i Miedzińskiego ${ }^{15}$, chociaż zaznaczyć trzeba, że w okresie rewolucyjnym praca wyszkoleniowa organizacji znacznie osłabła.

Kyiv branch.

${ }^{9}$ Used the code name «Janusz».

${ }^{10}$ Used the code names «Michalowski», «Malinowski».

${ }^{11}$ It is about the battle between the Austro-Hungarian and Russian armies during the Brusilov Offensive, which took place at Kostyukhnivka on 4-6 July 1916. After the escape of Hungarian units, the Polish legions, without artillery support, were forced to hold off attacks by superior Russian troops. As a result, the loss of killed, wounded and prisoners amounted to about $50 \%$.

${ }^{12}$ Most likely is Juliusz Zulauf, born in 1891. Prisoner of the Austrian army.

${ }^{13}$ Note by H. Jabłoński "P. Kaz. Domosławski - 'Edward'."

14 Tadeusz Schätzel von Murzhauzen (code names «Kopystyński», «Kopystyński Zdzisław», «Tomasz Krymski»), born in 1891, legionist. In January 1918 , as an emissary of PMO crossed the front line to establish contact with the military of the II and III Polish corps. From the spring of the same year served as a Deputy commandant of PMO, head of the organizational Department (Department I).

${ }^{15}$ Bohusław Miedziński (code names «Andrzej Świtek», «Świtek», «Stanisław 
IНТЕРМАРУМ: історія, політика, культура. - Вип. 6.

Miedziński i Schätzel przyjechali z pełnomocnictwami z kraju i rozporządzając znacznemi funduszami rozszerzyli ramy organizacyjne. Zorganizowali konspiracijne biuro, wydawali już pisemne rozkazy. Całą kancelarję oparli na zasadach wojskowych.

Jeśli chodzi o kontakt na zewnątrz Kijowa, to myśmy podtrzymowali go tylko z Odessą. Ja raz czy dwa razy jeździłem z polecenia Bromirskiego do Odessy w ciągu tego całego czasu. W Zytomierzu zachowała się organizacja stworzona jeszcze przed wojną przez Drużyny Strzeleckie ${ }^{16}$. Organizacja ta, złożona $\mathrm{z}$ młodzieży gimnazialnej, pomimo, że była pozbawiona wszelkiej łączności z innemi ośrodkami roboty wojskowej, jednakże dzięki wysokiemu poziomowi ideowemu członków, przetrwała i nawet stała na dosyć wysokim poziomie technicznym, co mogłem stwierdzić osobiście, kiedy /po ich abcesie do organizacji Kijowskiej/ jeździłem z polecenia Bromirskiego na lustrację. Duszą roboty w Zytomierzu był Zgorzelski ${ }^{17}$.

Byłyśmy także w kontakcie z Petersburgiem, gdzie P.O.W. było w rękach inż. Franciszka Skąpskiego ${ }^{18}$. Skąpski wtedy uważał siebie za komendanta naczelnego na całą Rosje i później po rewolucji rosyjskiej, pod wpływem endeków, którym istnienie P.O.W. stało kością w gardle, wydał rozkaz rozwiązania całej tej organizacji. Wywołało to ostry konflikt i wymówienie posłuszeństwa Skąpskiemu przez cały okręg kijowski ${ }^{19}$ /o szczegółach tej sprawy mogą złożyć dodatkowe zeznanie./

W Petersburgu i Moskwie P.O.W. rekrutowała się glównie z młodzieży narodowej i podporządkowała się Skąpskiemu.

Zaleski», «Zaleski», «Zaporowski»), born in 1891. One of the founders of PMO, member of its General command. In 1915 went to Kyiv and Petersburg. In March-July of 1918 was a General command commandant of PMO 3.

${ }^{16}$ Polish independent organization, established in 1911 in Lviv and focused on the military and patriotic education of schoolchildren and students.

17 Jan Zgorzelski (code name «Ćwiek»). Deputy commandant of Zhytomyr district, Zhytomyr city commandant of PMO.

${ }^{18}$ Used the code names «Doliwa», «Karol Doliwa», born in 1881. In July 1915 he was appointed a chief commandant of the PMO in Russia.

${ }^{19}$ Erroneous Dating. It is about the arrival of Franciszek Skapski in Kiev in December 1916. After February 1917, he opposed the creation of the Polish army in Russia. This fact deepened the conflict with Józef Bromirski 98 
INTERMARUM: history, policy, culture. - Issue 6.

/Opowiadania p. Kazimierza Domosławskiego spisał Henryk Jabłoński. Warszawa 29.XI.1933 r./

\section{RELACJA USTNA}

Annex B.

Organizacje i ludzie/c.d/

Wiele ciekawych szczegółów z historji organizacyj korporanckich podać może adwokat Olechowicz ${ }^{20} \mathrm{z}$ Wilna /Mała Pohulanka 14 m.2/

Ciekawe jeszcze rzeczy $\mathrm{z}$ mało znanej historji harcerstwa kijowskiego podać może jego żona Wiktorja $\mathrm{z}$ domu Kanionkówna ${ }^{21}$. Była ona jedną z czynniejszych członkiń antyendeckiej opozycji lewicowej w harcerstwie i posiadała w niem wielkie wpływy. Pracowała ona również wybitnie w P.O.W. Należała ona pozatem do Unji Postępowo-Niepodległościowej.

Do dziejów Korporacji ciekawe szczegóły mogliby dorzucić Dr. med. Władysław Szendzikowski22, Dr. Marjan Kowalewski, dr. Romecki oraz dr. Dobrzyński, który nawet napisał wspomnienia z tych czasów i oddał je, zdaje się Bajerowi.

W ruchu akademickim czynny udział brała Zofja Dembowska ${ }^{23}$.

Brat Wiktorji, Józef Kamionko ${ }^{24}$ był wówczas ozcniem gimnazium, należał do P.O.W., do najmłodszej sekcji chłopców ćwiczących.

Do tej samej sekcji należeli m. in. Władysław Milanowski ${ }^{25}$, Torczalski ${ }^{26}$, Poniatowski ${ }^{27}$.

${ }^{20}$ Stanysław Olechowicz (code name «Litwinowicz»). Active member of the Harzer movement, member of PMO Kyiv branch.

${ }^{21}$ Wiktorja Olechowicz nee Kamionko (code name «Piotrowska»). Member of the Harzer movement, member of PMO Kyiv branch since 1915.

${ }^{22}$ Note by H. Jabłoński "Warszawa Nowogrodzka 37."

${ }^{23}$ Note by H. Jabłoński “Zoliborz. Warszawska Spóldzielnia Mieszkaniowa.”

${ }^{24}$ Józef Kamionko (code names «Lapis», «Bujwid», «Jasieńczyk»).

${ }^{25}$ Note by H. Jabłoński "Warszawa Floriańska 12."

${ }^{26}$ Most likely it is about Heliodor Torczalski, who used the code name «Kowalski». Member of PMO Kyiv branch since 1916.

${ }^{27}$ Note by H. Jabłoński “Obecnie ekonomsta.”. Most likely it is about Zigmunt Poniatowski. 
IНТЕРМАРУМ: історія, політика, культура. - Вип. 6. ISSN 2518-7694 (Print)

ISSN 2518-7708 (Online)

Z czynnych w P.O.W. kobiet wymienić jeszcze należy p. Sikorską, oraz Wandę Wasilewska ${ }^{28}$, żonę Leona.

Ciekawe szczegóły z życia, Józefa Bromirskiego podać mógłby zapewne jeden $\mathrm{z}$ jego osobistych przyjaciół - Grablis ${ }^{29}$ pracujący do niedawna w Banku Komunalnym w Warszawie, - oraz Stanisław Fedecki ${ }^{30}$, obecnie, zdaje się, inspektor pracy.

Wiadomości bliższych o Arciniowskim udzielićby może mogła siostra jego Paulina Chudkowska.

\section{Потапенко МаксИм. СВІДЧЕННЯ КАЗІМІРА ДОМОСЛАВСЬКОГО ПРО ДІЯЛЬНІСТЬ ПОЛЬСЬКОЇ ОРГАНІЗАЦІЇ ВІЙСЬКОВОЇ У КИЕВІ В 1915 - 1918 РОКАХ}

\section{Анотація}

До наукового обігу вводиться повний текст свідчень визначного польського політичного діяча Казіміра Домославського про початковий етап діяльності Польської організаиії військової в Україні

Ці свідчення були зафіксовані Генриком Яблонським наприкіниі 1933 року в ході збирання усних свідчень для дослідження польської автономії в Наддніпрянській Украйні у 1917-1918 роках. Головною темою свідчень $\epsilon$ діяльність київського осередку Польської організачії військової впродовж 1915-1918 років. Київька філія иієї організації відіграла важливу роль у начіональному житті поляків Наддніпрянської України під час Першої світової війни.

Казимір Домославський був співробітником польського товариства допомоги жертвам війни, керував діяльністю київських відділень студентської «Корпорачії» та Польської сочіалістичної партії (револючійної фракиії). Його політична кар'єра досягла свого апогею в 1917 р. Потім він став членом Центральної Ради України, членом Київської міської Думи, головою ІІ Конферениї Польської соціалістичної партії в Росії. Те, що Казимір Домославський був учасником Польської організаиії військової мало відома інформачія. Це означає, щзо існували тісні контакти між легальною польською соиіалістичною партією (революиійною фракиією) та підпільною польською військовою організацією. Основна тема свідчень - діяльність київського відділення Польської організаиії військової у 1915-1918 рр. Цей час був одним з

${ }^{28}$ Wanda Wasilewska nee Zelenewska.

${ }^{29}$ Most likely it is about Ignacy Grablis.

${ }^{30}$ Born in 1894 . In $1914-1917$ is a student of Kyiv university. 100 
INTERMARUM: history, policy, culture. - Issue 6.

найбільи визначальних періодів у діяльності організації. У дослідженні здійснюється внутрішня та зовнішня критика джерела, підтверджується його висока інформативність. Проаналізовано співвідношення иих свідчень із пізнішими спогадами Казимира Домославського, опублікованими у 1923 роиі. Доказом високого рівня надійності показань є те, щзо всі згадані особи були членами Польської організаиії військової (результати досліджень Олександра Голіченка).

Ключові слова: Казімір Домославський, Генрик Яблонський, Польська організація військова, Київ, Украӥнська революиія 1917-1921 років.

\section{Maksym Potapenko. RELACJE KAZIMIERZA DOMOSLAWSKIEGO O DZIALALNOŚCI POLSKIEJ ORGANIZACJI WOJSKOWEJ W KIJOWIE WLATACH 1915-1918.}

\section{Streszczenie}

Niniejsza praca wprowadzaw naukowy obieg petny tekst zeznań Kazimierza Domostawskiego - wybitnego polskiego polityka, który na początku XX wieku przebywat na Ukrainie. Zeznania zostaty spisane przez Henryka Jabłońskiego pod koniec 1933 roku $w$ czasie zbierania ustnych zeznań dotyczacych badań nad polska autonomia na Naddnieprzańskiej Ukrainie $w$ latach 1917-1918. Głownym tematem zeznań jest działalność kijowskiego oddziatu Polskiej Organizacji Wojskowej w latach 1915-1918. We wstęnej częśsi artykulu została podjęta analiza wewnętrzna i zewnętrzna źródta, która potwierdza jego wysoki charakter informacyjny. Przeanalizowano również zwiazek zeznań Kazimierza Domosławskiego z jego wspomnieniami opublikowanymi w 1923 roku.

Stowa kluczowe: Kazimierz Domosławski, Henryk Jabłonski, Polska Organizacja Wojskowa, Kijów, Ukraińska rewolucja w latach 1917-1921.

The article was received 08.29.2019 Article recommended for publishing 09.27.2019 